\title{
John Locke: Theorist of Empire?
}

\section{Citation}

Armitage, David. 2012. John Locke: Theorist of empire? In Empire and Modern Political Thought, ed. Sankar Muthu, 84-111. Cambridge: Cambridge University Press.

\section{Published Version}

doi:10.1017/CB09781139016285.005

\section{Permanent link}

http://nrs.harvard.edu/urn-3:HUL.InstRepos:10718367

\section{Terms of Use}

This article was downloaded from Harvard University's DASH repository, and is made available under the terms and conditions applicable to Other Posted Material, as set forth at http:// nrs.harvard.edu/urn-3:HUL.InstRepos:dash.current.terms-of-use\#LAA

\section{Share Your Story}

The Harvard community has made this article openly available.

Please share how this access benefits you. Submit a story.

Accessibility 


\title{
John Locke: Theorist of Empire? $\dagger$
}

\author{
DAVID ARMITAGE \\ Department of History, Harvard University
}

Even twenty-five years ago, it might have been eccentric to ask whether John Locke was a theorist of empire. Within the shorthand history of political thought, Locke was the grandfather of liberalism; in the standard histories of philosophy, he was the exemplar of empiricism. Liberalism had long been assumed to be incompatible with empire and the main links between empiricism and imperialism were generally found in the work of Francis Bacon and the seventeenth-century Royal Society. However, a generation of recent scholarship has fundamentally revised understandings of liberalism's relation to empire and in particular of Locke's relationship to settler colonialism in North America and beyond. ${ }^{1}$ The impact of this work has been so widespread that, alongside Locke the alleged founder of liberalism and Locke the pivotal empiricist, we now find 'Locke, the champion of big property, empire, and appropriation of the lands of Amerindians'. ${ }^{2}$ Locke has finally joined the canon of theorists of empire: but how much does he deserve his place there?

\footnotetext{
$\dagger$ Published in Sankar Muthu, ed., Empire and Modern Political Thought (Cambridge, 2012), pp. 84-111. For their detailed comments on earlier versions of this chapter, I am especially grateful to Daniel Carey, Tim Harris, Karuna Mantena, Nagamitsu Miura, Sankar Muthu, Kiyoshi Shimokawa, and Sonoko Yamada. It arises from my work on an edition of Locke's colonial writings for the Clarendon Edition of the Works of John Locke: I owe special thanks to Mark Goldie, John Milton, and James Tully for their patient support of that project. I am also grateful to Tom Leng and Kiyoshi Shimokawa for sharing work in advance of publication.

1 See especially James Tully, 'Rediscovering America: The Two Treatises and Aboriginal Rights', in Tully, An Approach to Political Philosophy: Locke in Contexts (Cambridge, 1993), 137-76; Barbara Arneil, John Locke and America: The Defence of English Colonialism (Oxford, 1996); Duncan Ivison, 'Locke, Liberalism and Empire', in Peter R. Anstey, ed., The Philosophy of John Locke: New Perspectives (London, 2003), 86-105; David Armitage, 'John Locke, Carolina, and the Two Treatises of Government', Political Theory, 32 (2004), 602-27; James Farr, 'Locke, Natural Law, and New World Slavery', Political Theory, 36 (2008), 495-522. On the more general turn to the study of empire among political theorists and historians of political thought, see Jennifer Pitts, 'Political Theory of Empire and Imperialism', Annual Review of Political Science, 13 (2010), 211-35.

2 Jonathan Israel, 'Enlightenment! Which Enlightenment?', Journal of the History of Ideas, 67 (2006), 529; however, see Israel, Enlightenment Contested: Philosophy, Modernity, and the Emancipation of Man, 1670-1752 (Oxford, 2006), 546, 603-5, for a more moderate admission that 'it is perhaps not entirely fair to depict Locke as an ideologist of empire': ibid., 604.
} 
What it might mean to be a theorist of empire was profoundly shaped by the experience and practices of imperialism in the two centuries between roughly 1757 and 1960: that is, from the beginnings of European military dominance in South Asia to the first great wave of formal decolonization outside Europe. James Tully has succinctly summarized the key features European imperial vision in this period:

It is 'imperial' in three senses of this polysemic word. It ranks all nonEuropean cultures as 'inferior' or 'lower' from the point of view of the presumed direction of European civilisation towards the universal culture; it serves to legitimate European imperialism, not in the sense of being 'right' ... but, nevertheless, in being the direction of nature and history and the precondition of an eventual, just, national and world order; and it is imposed on non-European peoples as their cultural self-understanding in the course of European imperialism and federalism. ${ }^{3}$

Tully's immediate example here was Immanuel Kant viewed through the lens of Edward Said's Culture and Imperialism (1993), but accounts of the relationship between Locke and empire have shared many of the same assumptions. He has been held to be an 'imperial' thinker in all three senses: because he placed the world's peoples in a hierarchical order with Europeans at the top of the scale; because he legitimated European imperialism within a progressivist vision of history; and because he proposed European capacities - specifically, Europeans' rationality - as a universal standard against which other peoples were to be judged and towards which they were to be led. ${ }^{4}$ On these grounds, there would now be widespread agreement that Locke has as much claim to be a theorist of empire as any other proponent of the 'self-consciously universal

\footnotetext{
3 James Tully, Public Philosophy in a New Key: II, Imperialism and Civic Freedom (Cambridge, 2008), 27 (italics Tully's).

4 See especially Bhikhu Parekh, 'Liberalism and Colonialism: A Critique of Locke and Mill', in Jan Nederveen Pieterse and Bhikhu Parekh, eds., The Decolonization of Imagination: Culture, Knowledge and Power (London, 1995), 81-98; Uday Singh Mehta, Liberalism and Empire: A Study in Nineteenth-Century British Liberal Thought (Chicago, 1999). For acute questionings of the assumptions summarized here, see Daniel Carey and Sven Trakulhun, 'Universalism, Diversity, and the Postcolonial Enlightenment', in Daniel Carey and Lynn Festa, eds., Postcolonial Enlightenment: Eighteenth-Century Colonialism and Postcolonial Theory (Oxford, 2009), 240-80, and Vicki Hsueh, Hybrid Constitutions: Challenging Legacies of Law, Privilege, and Culture in Colonial America (Durham, NC, 2010), 1-24.
} 
... political, ethical and epistemological creed' of liberalism, including Bentham, the James and John Stuart Mill, and Macaulay (to take only British examples). ${ }^{5}$

The philosophical distance between Locke and Kant, or between Locke and the Utilitarians, should give pause before affirming that consensus, as should the differences between the forms and conceptions of empire found in the seventeenth century and the nineteenth century. ${ }^{6}$ This chapter's argument will be that Locke was clearly a colonial thinker. However, it also argues that the label 'imperial' cannot be aptly applied to him because he did not espouse or elaborate a hierarchical ordering of populations, least of all one that places Europeans above or even apart from other groups, because he saw rationality itself as evenly distributed among human populations and the usual markings of civilization as contingent and fragile. It concludes that some of the specifically Atlantic features of Locke's thought can be explained by his connections with English colonial activity, and that he provided only limited grounds on which later 'imperial' thinkers could erect their justifications for European settlement and indigenous dispossession.

\section{John Locke, Colonial Thinker}

There can be no doubt that Locke was a specifically colonial thinker, if by that we mean simply someone who devoted much thought and attention to the settlement and governance of colonies. He was in fact more deeply involved in the practical business of promoting and running overseas settlements than any European political thinker between the early seventeenth century, when Hugo Grotius wrote legal briefs for the Dutch East India Company, and the nineteenth century, when the Mills worked for the British East

\footnotetext{
5 Mehta, Liberalism and Empire, 1. For an illuminating critique of this reading of liberalism, see Jennifer Pitts, A Turn to Empire: The Rise of Imperial Liberalism in Britain and France (Princeton, 2005).

6 On Kant and empire, see especially Sankar Muthu, Enlightenment Against Empire (Princeton, 2003), ch. 5; on the varieties of empire, see David Armitage, ed., Theories of Empire, 1450-1800 (Aldershot, 1998), Andrew Porter, 'From Empire to Commonwealth of Nations', in Franz Bosbach and Hermann Hiery, eds., Imperium/Empire/Reich. Ein Konzept politischer Herrschaft im deutsch-britischen Vergleich (Munich, 1999), 167-78, and James Tully, 'Lineages of Contemporary Imperialism', in Duncan Kelly, ed., Lineages of Empire: The Historical Roots of British Imperial Thought (Oxford, 2009), 3-29.
} 
India Company. ${ }^{7}$ His first administrative position was as secretary to the Lords Proprietors of Carolina from 1669 to 1675, when he was involved in drafting the Fundamental Constitutions of Carolina (1669, and later revisions). ${ }^{8}$ Among the provisions of Carolina's first frame of government were the creation of a class of hereditary 'leet men' who were tied to the land and the introduction of chattel slaves, over whom every 'freeman of Carolina' had 'absolute power and authority', that is, the power of life and death. ${ }^{9}$

Locke never dissented, publicly or privately, from the harshest provisions of the Fundamental Constitutions, although he may also have played some role in expanding Carolina's boundaries of religious toleration and the protection of indigenous people. The Constitutions enshrined toleration for all theists, including 'heathens, Jews, and other dissenters from the purity of the Christian religion'. There is also later testimony that Locke opposed another of its provisions establishing the Church of England in Carolina, and he may have been responsible for the supplementary laws added to the Constitutions in 1671 which banned the enslavement of local Indians. ${ }^{10}$ The Proprietors clearly approved of Locke's work for, in April 1671, they made him a hereditary 'landgrave' of the colony for his great wisdom, learning and industry in drawing up the its form of government and establishing it on the Ashley River in Carolina (magna sua prudentia, eruditione et industria tam in stabilienda regiminis forma, quam in Coloniis ad Flumen

\footnotetext{
7 On Grotius, see Martine Julia van Ittersum, Profit and Principle: Hugo Grotius, Natural Rights Theories and the Rise of Dutch Power in the East Indies, 1595-1615 (Leiden, 2006); on the Mills and their milieu, see especially Eric Stokes, The English Utilitarians and India (Oxford, 1959), Bart Schulz and Georgios Varouxakis, eds., Utilitarianism and Empire (Lanham, MD, 2005), and the chapter by Pratap Bhanu Mehta in this volume.

8 The evidence for Locke's hand in the Fundamental Constitutions is assessed in J. R. Milton, 'John Locke and the Fundamental Constitutions of Carolina', The Locke Newsletter, 21 (1990), 111-33, Armitage, 'John Locke, Carolina, and the Two Treatises of Government', and Philip Milton, 'Pierre Des Maizeaux, A Collection of Several Pieces of Mr. John Locke, and the Formation of the Locke Canon', EighteenthCentury Thought, 3 (2007), 260-5.

9 The Fundamental Constitutions of Carolina (1669), §§ 22-3, 101, in John Locke, Political Essays, ed. Mark Goldie (Cambridge, 1997), 166, 180.

10 The Fundamental Constitutions of Carolina, § 87, in Locke, Political Essays, ed. Goldie, 178; John Marshall, John Locke, Toleration and Early Enlightenment Culture (Cambridge, 2006), 599-600; A Collection of Several Pieces of Mr. John Locke, Never before Printed, or Not Extant in his Works, ed. Pierre Des Maizeaux (London, 1720), 42 n.; The [British] National Archives, Kew (hereafter, NA), CO 5/286, fol. 41 ${ }^{\text {r }}$ Temporary laws for Carolina (December 1671), ptd. in [W. J. Rivers,] A Sketch of the History of South Carolina to the Close of the Proprietary Government by the Revolution of 1719 (Charleston, SC, 1856), 353. These 'laws' are in Locke's handwriting.
} 
Ashleium collocandis). Locke never took up his 48,000-acre land-grant and at one point tried to sell his title but he never repudiated his collaboration with the Proprietors and seems to have taken pride in the Fundamental Constitutions right up to his death in 1704. ${ }^{11}$

By virtue of his connections to Carolina, Locke became the first European philosopher since Michel de Montaigne over a century before to meet and interrogate Native Americans in Europe. In 1670, two sons of the 'Emperor' of the Kiawah Creek town of Cofitachequi in Carolina travelled to England by way of Barbados. They were named, by the English at least, Honest and Just. Little is known about their movements before they returned to Carolina in 1672, but it is clear that Locke spoke to them before he had completed the second draft of his Essay Concerning Human Understanding in 1671.' In what is now known as 'Draft B' of the Essay, he compared mathematical computation to human language and speculated that all counting consisted of only three operations: addition, subtraction, and comparison. If a number becomes so large that it cannot be redescribed using the names of smaller numbers, Locke argued, it becomes impossible to conceive the idea of such an enormous sum:

... And this I thinke to be the reason why some Indians I have spoken with, who were otherwise of quick rationall parts could not as we doe count to a 1000. though they could very well to 20 because their language being scanty $\&$ accomodated only to the few necessarys of a needy simple life unacquainted either with trade or Mathematiques, had noe words in it to stand for a thousand. soe that if you discoursed with them of those great numbers they would shew you the hairs of their head to expresse a great multitude which they could not number. ${ }^{13}$

When Locke incorporated a revised version of this passage into the published Essay (1690), he compared the constraints on the mathematical knowledge of the 'Americans'

11 Bodleian Library, Oxford, Locke Manuscripts (hereafter, Bod. MS Locke), b. 5/9 (4 April 1671); Armitage, 'John Locke, Carolina, and the Two Treatises of Government', 608-11.

12 St. Julien R. Childs, 'Honest and Just at the Court of Charles II', South Carolina Historical Magazine, 64 (1963), 27; Alden T. Vaughan, Transatlantic Encounters: American Indians in Britain, 1500-1776 (Cambridge, 2006), 104; Farr, 'Locke, Natural Law, and New World Slavery', 498; Farr, 'Locke, "Some Americans", and the Discourse on "Carolina"', Locke Studies, 9 (2009), 19-77.

13 John Locke, 'Draft B' (1671) of the Essay, § 50, in Drafts for the Essay Concerning Human Understanding and Other Philosophical Writings, eds. Peter H. Nidditch and G. A. J. Rogers, 3 vols. projected (Oxford, 1990- ), I, 157 (my emphasis). 
with the similar limits on Europeans' rational capacities: 'I doubt not but we our selves might distinctly number in Words, a great deal farther than we usually do, would we find out but some fit denominations to signifie them by'.14 Such scepticism would be characteristic of his later writings on the subject. The encounter with Honest and Just helped to shape Locke's conception of Native Americans' rational capacities and prevented him from concluding that Europeans alone possessed any superior cultural self-understanding.

Between 1672 and 1676, Locke followed his patron the first Earl of Shaftesbury in becoming a stockholder and co-proprietor in a company set up to trade between the Bahamas and the American mainland. ${ }^{15}$ In September 1672, he was also named in the charter of the Royal African Company, the English monopoly for trading in slaves. ${ }^{16}$ In 1673-4, he became secretary and then also treasurer to the Council for Trade and Foreign Plantations. ${ }^{17}$ Moreover, from 1696 until ill-health forced him to relinquish office in 1700, Locke was among the first Commissioners appointed to the English Board of Trade, the main administrative body which oversaw the commerce and colonies of the Atlantic world. While in that post, he assured a correspondent in Virginia that " $\mathrm{t}] \mathrm{he}$ flourishing of the Plantations under their due and just regulations [is] that which I doe and shall always aim at', and he was always as active in its counsels as his fragile health would permit. ${ }^{18}$ His administrative duties and financial investments over the course of

14 John Locke, An Essay Concerning Human Understanding, ed. Peter H. Nidditch (Oxford, 1975), 207 (II. xvi. 6).

15 Hampshire Record Office, Winchester, Malmesbury Papers, 7M54/232, Articles of Agreement of the Bahamas Adventurers (4 September 1672); British Library, London (hereafter, BL), Add. MS 15640, fols. $3^{\mathrm{r}}-8^{\mathrm{v}}, 9^{\mathrm{r}}-15^{\mathrm{r}}$; K. H. D. Haley, The First Earl of Shaftesbury (Oxford, 1968), 232-3. On Shaftesbury's colonial vision, see Tom Leng, 'Shaftesbury's Aristocratic Empire', in John Spurr, ed., Anthony Ashley Cooper, First Earl of Shaftesbury, 1621-1683 (Farnham, 2011), 101-26.

16 NA, C 66/3136/45, CO 268/1/11 (27 September 1672).

17 Library of Congress, Washington, D.C, Phillipps MS 8539, pt. 1, Journals of the Council for [Trade and] Foreign Plantations, 1670-4; Ralph Paul Bieber, 'The British Plantation Councils of 1670-4', English Historical Review, 40 (1925), 93-106; Eva Botella-Ordinas, 'Debating Empires, Inventing Empires: British Territorial Claims Against the Spaniards in America, 1670-1714', Journal for Early Modern Cultural Studies, 10 (2010), 142-50.

18 Locke to James Blair, 16 October 1699, in The Correspondence of John Locke, ed. E. S. de Beer, 8 vols. to date (Oxford, 1976- ), VI, 706; Peter Laslett, 'John Locke, the Great Recoinage and the Origins of the Board of Trade 1695-1698', in John Yolton, ed., John Locke: Problems and Perspectives (Cambridge, 1969), 137-64; Michael Kammen, 'Virginia at the Close of the Seventeenth Century: An Appraisal by James Blair and John Locke', Virginia Magazine of History and Biography, 74 (1966), 141-69; Jack 
four decades earned Locke practical experience of English colonial and commercial activity in North America, from New York to Carolina, in the Caribbean, Ireland, and Africa. ${ }^{19}$ By the time he resigned from the Board of Trade in June 1700, he had become one of the two best-informed observers of the English Atlantic world of the late seventeenth century: only his rival on the Board of Trade, the career administrator Sir William Blathwayt, had a more comprehensive command of English colonial administration by that time. ${ }^{20}$

Locke's experience in colonial administration both widened his horizons and focused his interests. During the closing decades of the seventeenth century, when Locke was most involved in colonial affairs, 'there is evidence of sharpening legal distinctions between the Atlantic and the Indian Ocean'. The Board of Trade's activities concentrated almost entirely on the Atlantic world and they considered affairs in the Indian Ocean only when they had implications for that arena, as in the case of global piracy, for example. ${ }^{21}$ His economic writings provide evidence that his imperial vision was similarly bounded by the Atlantic. There is a single reference to the Indian Ocean arena in his economic writings, when he implored an antagonist 'please to remember the great Sums of Money ... carried every year to the East-Indies, for which we bring home consumable Commodities'. ${ }^{22}$ And Locke mentioned the East India Company only once in print, in his Second Letter Concerning Toleration (1690), when he taxed an interlocutor with failing to see that 'Civil Society' has different goals from other forms of human association: 'By which account there will be no difference between Church and State; A Commonwealth and an Army; or between a Family and the East-India Company; all which have hitherto

Turner, 'John Locke, Christian Mission, and Colonial America', Modern Intellectual History, 8 (2011), 267-97.

19 Most of his practical writings relating to colonial matters will appear in John Locke, Colonial Writings, ed. David Armitage (Oxford, forthcoming).

20 Barbara C. Murison, 'The Talented Mr Blathwayt: His Empire Revisited', in Nancy L. Rhoden, ed., English Atlantics Revisited: Essays Honouring Professor Ian K. Steele (Montreal and Kingston, 2007), 334.

21 Lauren Benton, 'Legal Spaces of Empire: Piracy and the Origins of Oceanic Regionalism', Comparative Studies in Society and History, 47 (2005), 718; NA, CO 324/6, fols. 160r-64v, 166V-71r , 175; CO 5/1116, fols. 1r-17v; compare Bod. MS Locke c. 30, fols. 62-3, endorsed 'Pyracy 97'.

22 Philip J. Stern, "'A Politie of Civill \& Military Power": Political Thought and the Late SeventeenthCentury Foundations of the East India Company-State', Journal of British Studies, 47 (2008), 253-83; John Locke, Some Considerations of the Consequences of the Lowering of Interest, $2^{\text {nd }}$ edn. (1696), in Locke on Money, ed. Patrick Hyde Kelly, 2 vols. (Oxford, 1991), I, 333. 
been thought distinct sorts of Societies, instituted for different Ends' ${ }^{23}$ He did not invest in the New East India Company until after he had left the Board of Trade: even then, he held on to his bonds for less than a year, and sold them at a small loss in the summer of 1701.24

Locke's imperial vision was comparatively less wide-ranging than that of many contemporary English political economists. For example, Sir William Petty gradually expanded his range outward from the Three Kingdoms of Britain and Ireland to the Atlantic world and from there to a conception of an economically defined, globally dispersed, polity in which all of England's interests - British, American, African, and Asian - would be equally represented. ${ }^{25}$ No less comprehensive were the analyses of England's East India trade by Charles Davenant and Henry Martyn, who each saw Asian commerce as crucial to England's economic fortunes and to the elaboration of interoceanic and global trade more generally. On their analysis, bullion taken largely from the Americas could be exchanged in Asia both for luxury goods and for more widely affordable commodities such as the boomingly popular calicoes which were exported from India to England and the American colonies. For Martyn, in particular, the import of cheaper textiles from India may have undercut domestic English industry, but that was an unavoidable side-effect of comparative advantage to which protectionism could provide no solution: 'When we shall be reduc'd to plain Labour without any manner of Art, we shall live at least as well as the Wild Indians of America, the Hottantots of Africa, or the Inhabitants of New Holland', he remarked sardonically. Martyn drew heavily on Locke's comparison between the productive capacities of England and America in the Second Treatise (II. 41) to support his argument. This debt only pointed up the absence of the Asian trades in Locke's vision of political economy, an absence made all the more poignant by the fact that in 1696 Locke missed his chance

\footnotetext{
23 John Locke, A Second Letter Concerning Toleration (London, 1690), 51. It is therefore highly unlikely that the distinctive voting procedures of the East India Company inspired his conception of majority rule in the Two Treatises, pace Francesco Galgano, 'John Locke azionista delle compagnie coloniali (una chiave di lettura del Secondo trattato del governo)', Contratto e impresa, 23 (2007), 327-33, 340-1.

24 Bod. MS Locke c. 1, fols. 106, 107.

25 David Armitage, The Ideological Origins of the British Empire (Cambridge, 2000), 152-3; Ted McCormick, William Petty and the Ambitions of Political Arithmetic (Oxford, 2009), 230-3.
} 
to ask 'a Japonese' visitor to London 'whether the importation of gold and silver' was prohibited in his country. ${ }^{26}$

The limits of Locke's imperial vision become even clearer when we compare him with other seventeenth-century European contributors to the modern tradition of natural jurisprudence. For example, Grotius's fundamental writings on natural law sprang originally from his defence of the Dutch East India Company's activities in maritime south-east Asia, most notably in his The Free Sea (1609), the locus classicus for arguments in favour of freedom of trade across the oceans of the world, and a work Locke certainly knew. ${ }^{27}$ Later in the century, Samuel Pufendorf's conception of human sociability implied a potentially global conception of commercial society linking together the peoples of the world through mutually sustaining systems of utility and exchange. ${ }^{28}$ This 'neo-Aristotelian' vision of commercial sociability found its closest parallel in late seventeenth-century French Augustinianism, especially in the work of the French theologian and essayist, Pierre Nicole. As Nicole put it in his 'Treatise of Peace' (1671), using the example of Northern European trade with East Asia:

The world then is our citty: and as inhabitants of it, we have intercourse with all man kinde, And doe receive from them advantages, or inconveniencys [de l'utilité \& tantôt du dommage]. The Hollanders have a trade with Japan, we [the French] with Holland; and soe have a commerce with those people, at the farthest end of the world ... They are linked to us, on one side, or other; \& all entre into that chain, which ties the whole race of men togeather by their mutuall wants [besoins réciproques]. ${ }^{29}$

26 Istvan Hont, Jealousy of Trade: International Competition and the Nation-State in Historical Perspective (Cambridge, MA, 2005), 201-22, 245-58; Henry Martyn, Considerations upon the East-India Trade (London, 1701), 58, 72-3; Locke to Hans Sloane, 15 March 1697, in Correspondence, ed. de Beer, VI, 35-6. Sloane thought the visitor was Chinese, from 'Emoy' (present-day Xiamen): Sloane to Locke, 18 March 1697, ibid., VI, 56.

27 Hugo Grotius, The Free Sea, ed. David Armitage (Indianapolis, 2004); Grotius, Commentary on the Law of Prize and Booty, ed. Martine van Ittersum (Indianapolis, 2006). Locke possessed Grotius's Mare Liberum (1609) in an edition of Grotius, De jure belli ac pacis libri tres (The Hague, 1680), Bod. Locke 9. 99.

28 Richard Tuck, The Rights of War and Peace: Political Thought and the International Order from Grotius to Kant (Oxford, 1999), 167-72.

29 Hont, Jealousy of Trade, 45-51, 159-84; Pierre Nicole, 'Treatise Concerning the Way of Preserving Peace with Men' (1671), trans. John Locke, in John Locke as Translator: Three of the Essais of Pierre Nicole in French and English, ed. Jean S. Yolton (Oxford, 2000), 117. See also Richard Cumberland, $A$ Treatise of the Laws of Nature (1672), ed. Jon Parkin (Indianapolis, 2005), 318. 
Nicole's vision of global commerce appeared here only fleetingly but it contrasted starkly with Locke's own conception of commerce which was by default almost entirely confined to the Atlantic world. Locke certainly knew Nicole's work, for he translated the 'Treatise of Peace' in the mid-1670s. However, his political economy and political theory remained more limited than Nicole's and his universalism more constrained than either Grotius's or Pufendorf's in its range of reference. As we will see, this combination of cosmopolitanism and regional concentration characterized Locke's universalism, more broadly conceived.

\section{The Limits of Lockean Universalism}

Locke sometimes joked with friends about emigrating to New England or Carolina but he never travelled further west than his native county of Somerset. He did not even see the Atlantic Ocean until he was 56 years old, and then only from La Rochelle in France. In this regard, he can be compared to his friend Sir Isaac Newton who lived an entirely landlocked life while also acting, like Locke, as 'a fundamental link between the colonial information order and the empiricist knowledge regime forged in the final decades of the seventeenth century'. ${ }^{30}$ And yet, unlike Newton, Locke did spend long periods outside England, including almost four years travelling in France (1675-9) and six in exile in Holland (1683-9). His correspondence likewise comprised a nearly world-wide web: among the almost 4000 letters from and to him that survive, there are items from the Caribbean, New England, Virginia and Carolina, as well as from Bengal and China, not to mention extensive exchanges with friends and acquaintances in Scotland, Ireland, France, the Netherlands, Germany and Sweden. Among seventeenthcentury correspondence networks, only those of the Jesuit Athanasius Kircher and the philosopher Gottfried Wilhelm Leibniz were both larger in size and comparably farflung

30 Correspondence, ed. de Beer, I, 379, 590, II, 27, 34, 40, 68, 95, 105, 132, 141, 147, 441, 444; Bod. MS Locke f. 28, fol. 19; Locke's Travels in France, 1675-1679, as Related in his Journals, Correspondence and Other Papers, ed. John Lough (Cambridge, 1953), 232: 'This is the first time I ever saw the Ocean' (7 September 1678); Simon Schaffer, 'Newton on the Beach: The Information Order of Principia Mathematica', History of Science, 47 (2009), 247. 
in extent. ${ }^{31}$ During his years in Europe he collected numerous accounts of the extraEuropean world. By the time of his death, Locke's collection of travel literature was one of the largest ever assembled in Britain and it comprised 195 books, many maps, and a portfolio of ethnographic illustrations 'of the inhabitants of severall remote parts of the world espetially the East Indies', which included representations of Laplanders, Brazilian 'Cannibal[s]', 'Hottentot[s]' from the Cape of Good Hope, and of inhabitants of Java, Amboina, Macassar, Malaya, Ternate, Tonkin, Japan, China and 'Tartary'. 32

In the course of compiling his major published works, Locke mined his library and pressed his global connections for data about matters medical, theological, ethnographical, social, and political. Their greatest impact could be found in the first five editions of the Essay Concerning Human Understanding (1690-1706), in which information regarding the diversity of human beliefs provided crucial ammunition for his arguments against the supposed innateness of ideas. The key test-case for innatism was the idea of God. If even that seemingly most fundamental of ideas could not be shown to be universal, Locke argued, then surely no other could be said to be inborn, 'since it is hard to conceive, how there should be innate Moral Principles, without an innate Idea of a Deity'. He offered evidence to the contrary from the accounts of what 'Navigation discovered, in these latter Ages'. Not content with one or two examples to combat innatism, he continued to add empirical material to this passage and other similar ones until in the first posthumous edition of the Essay (1706), 'the number of authorities he had cited had risen to 16 .... The locations they described ranged from the Caucasus and Lapland to Brazil, Paraguay, Siam, China, the Cape of Good Hope, and elsewhere'. In this way, Locke made greater use of ethnographic information than any other philosopher in Britain before the eighteenth century. ${ }^{33}$

31 Mark Goldie, 'Introduction', in John Locke: Selected Correspondence, ed. Goldie (Oxford, 2002), viii, xviii; Paula Findlen, ed., Athanasius Kircher: The Last Man Who Knew Everything (New York, 2004); Paul Lodge, ed., Leibniz and His Correspondents (Cambridge, 2004).

32 BL Add. MS 5253; Locke to William Charleton, 2 August 1687, in Locke, Correspondence, ed. de Beer, III, 240.

33 Locke, Essay Concerning Human Understanding, ed. Nidditch, 87-8 (I. iv. 8); Daniel Carey, Locke, Shaftesbury, and Hutcheson: Contesting Diversity in the Enlightenment and Beyond (Cambridge, 2006), 71-92; Carey, 'Locke, Travel Literature, and the Natural History of Man', The Seventeenth Century, 11 (1996), 263. Locke had earlier invoked the atheism of the inhabitants of Brazil and Soldania Bay in the Essays on the Law of Nature (c. 1663-4): Locke, Essays on the Law of Nature and Associated Writings, ed. W. von Leyden (Oxford, 1954), 172-4/173-5 (Latin/English). 
Locke's knowledge of travel literature, and the information he gathered as a servant of English colonial ventures, encouraged his scepticism about human capacities and about the alleged superiority of Europeans. In the early lectures he gave at Oxford that are now known as the Essays on the Law of Nature (c. 1663-4), Locke had judged the 'primitive and untutored tribes [barbaras ... et nudas gentes]' harshly, 'since among most of them appears not the slightest trace or track of piety, merciful feeling, fidelity, chastity, and the rest of the virtues'. To this extent, he did not distinguish between the peoples 'of Asia and America who do not consider themselves to be bound by the same laws, separated from us as they are by long stretches of land and unaccustomed to our morals and beliefs [nec moribus nostris aut opinionibus assueti]'. ${ }^{34}$ This recognition of diversity served the purposes of Locke's evolving criticism of innate ideas but his evaluation of that diversity would become more complex in his later writings, starting in the late 1660 s and early 1670s. His developing arguments in this regard do not easily fit the imperial stereotype of an imperial theorist who ranked the peoples of the world hierarchically and placed some within, but many outside, the pale of liberalism.

It is now a commonplace that liberalism of the kind often traced back to Locke was both inclusive and universal in theory, but exclusionary and contingent in practice. As the most eloquent and subtle proponent of this view has put it, 'as a historical phenomenon, the period of liberal history is unmistakably marked by the systematic and sustained political exclusion of various groups and "types" of people'.35 Among the categories of persons denied the benefits and rights that liberalism theoretically promised to all human beings were, variously, indigenous peoples, the enslaved, women, children, and the mentally disabled, those whom Locke called 'mad Men' and 'Idiots'. The main criterion used to exclude such persons was their lack of rationality, and it has been argued that ' $[\mathrm{t}]$ he American Indian is the example Locke uses to demonstrate a lack of reason'. ${ }^{36}$ Yet, as we have seen, Locke did not charge Native Americans with irrationality even

\footnotetext{
34 Locke, Essays on the Law of Nature, ed. von Leyden, 140/1, 162/3 (Latin/English).

35 Mehta, Liberalism and Empire, 46-7 (on exclusion, quoted), 52-64 (on Locke); compare Mehta, 'Liberal Strategies of Exclusion', Politics and Society, 18 (1990), 427-54; Andrew Sartori, 'The British Empire and Its Liberal Mission', Journal of Modern History, 78 (2006), 623-42; Jack P. Greene, ed., Exclusionary Empire: English Liberty Overseas, 1600-1900 (Cambridge, 2010).

36 Barbara Arneil, 'Citizens, Wives, Latent Citizens and Non-Citizens in the Two Treatises: A Legacy of Inclusion, Exclusion and Assimilation', Eighteenth-Century Thought, 3 (2007), 209-22, 216 (quoted).
} 
when he convicted them of impiety, mercilessness, infidelity, promiscuousness, and other vices in 1663-4. Indeed, as we have also seen, in 1671 he wrote of the 'quick rationall parts' of the Carolina Indians he had interviewed in England.

Only in the First Treatise of Government did Locke ever call indigenous peoples 'irrational', and then solely as a means of praising their untutored wisdom over the sophistication of supposedly civilized nations: 'He that will impartially survey the World ... will have reason to think, that the Woods and Forests, where the irrational untaught Inhabitants keep right by following Nature, are fitter to give us Rules, than Cities and Palaces, where those that call themselves Civil and Rational, go out of their way, by the Authority of Example' (I. 58). ${ }^{37}$ Locke generally found greater inequalities of capacity within particular peoples than he did between them. In this vein, he argued in The Conduct of the Understanding (1697), 'Amongst men of equall education there is great inequality of parts. And the woods of America as well as the Schools of Athens produce men of severall abilitys in the same kinde'. ${ }^{38}$ The more fundamental difference between 'Americans' and Europeans therefore lay not in their intellectual abilities but in their contingent circumstances, their education, and their needs as shaped by their environment.

Locke argued consistently throughout his works that God sends us into this world without innate ideas or any of the other physical 'conveniencies of life' (to use a favourite Lockean turn of phrase). It was necessary for human beings to exercise their physical and their mental labour upon the otherwise inert creation given to them by God, this being 'the Condition of Humane Life, which requires Labour and Materials to work on' (II. 35). ${ }^{39}$ Human beings could neither add to nor subtract from the divine creation but they had a duty to construct it to their own devices, both mentally and physically. What we might call Locke's 'constructivist' understanding of human labour was basic to his epistemology in the Essay Concerning Human Understanding:

37 John Locke, Two Treatises of Government, ed. Peter Laslett, rev. edn. (Cambridge, 1988), 183. All references in the text are to this edition, by Treatise and paragraph number, unless otherwise noted.

38 John Locke, Of the Conduct of the Understanding, ed. Paul Schuurman (Keele, 2000), 156.

39 Compare E. J. Hundert, 'The Making of Homo Faber: John Locke between Ideology and History', Journal of the History of Ideas, 33 (1972), 3-22. 
The Dominion of Man, in this little World of his own Understanding, being much the same, as it is in the great World of visible things; wherein his Power, however managed by Art and Skill, reaches no farther, than to compound and divide the Materials, that are made to his Hand ..... ${ }^{40}$

It is up to us to furnish ourselves with a stock of ideas just as we must transform nature into materials for our use: '.. it is want of Industry and Consideration in us, and not of Bounty in him, if we have them not' (Essay, I. iv. 16). Thus, even the idea of God himself could be lacking, just as physical constructions like bridges or houses will be, if humans do not act industriously, if they fail to seize their God-given opportunities, or if they are constrained by their own reduced circumstances like the people of the 'West Indies':

... nature furnish[es] us only with the materials for the most part rough and unfitted to our uses it requires labour art and thought to suit them to our occasions, and if the knowledg of men had not found out ways to shorten the labour and improve severall things which seem not $\mathrm{a}[\mathrm{t}]$ first sight to be of any use to us we should spend all our time to make a scanty provision for a poore and miserable life. a sufficient instance whereof we have in the inhabitants of that large and fertill part of the world the west Indies who lived a poore uncomfortable laborious life with all their industry scarce able to subsist and that perhaps only for want of knowing the use of that stone out of which the Inhabitants of the old world had the skill to draw Iron $\ldots . . .1$

The presence or lack of adequate tools or commodities could account entirely for the differential productivity of particular peoples. Such conveniences are accidental and external; they bear no relation to the supposedly innate capacities of individuals or groups.

Locke was a thorough-going species nominalist and did not argue for any inherent ethnic, let alone, racial difference. Any people could go up or down the scale of civility according to the materials nature had given to them: 'were the use of Iron lost among us, we should in a few Ages be unavoidably reduced to the Wants and Ignorance of the ancient savage Americans, whose natural Endowments and Provisions come no way short

\footnotetext{
40 Locke, Essay, ed. Nidditch, 120 (II. ii. 2).

41 John Locke, 'Understanding' (8 February 1677), Bod. MS Locke f. 2, p. 44, ptd. in Locke, Political Essays, ed. Goldie, 261.
} 
of those of the most flourishing and polite Nations'. ${ }^{42} \mathrm{He}$ also believed firmly in the rationality of native Americans and that the advantages enjoyed by Europeans, even by philosophers like himself, were accidental: 'had the Virginia King Apochancana, been educated in England, he had, perhaps, been as knowing a Divine, and as good a Mathematician, as any in it'. ${ }^{43}$ The lack of those advantages could just as easily make the English irrational as Native Americans had become because they lacked certain human inventions: "perhaps without books we should be as ignorant as the Indians whose minds are as ill-clad as their bodies'. ${ }^{44}$ Locke's stress on the contingency and the reversibility of so much that later thinkers took to be the marks of higher civilization therefore makes it impossible to call him an imperial theorist on the grounds that he ranked cultures within a progressivist vision of human history.

\section{Locke and the Legitimation of Empire}

Locke can only be described as a theorist of empire in a narrowly restricted definition of that term. In early modern usage, the meanings of 'empire' clustered around two main referents: empire as sovereignty (imperium), and empire as a composite state. ${ }^{45}$ Locke would certainly have recognized the meaning of 'empire' as sovereignty or imperium and understood it to be territorial in application, as in the passage in the Second Treatise where he described how the 'several States and Kingdoms' of the world 'have, by positive agreement, settled a Property amongst themselves, in distinct Parts and parcels of the Earth' (II. 45). However, there is no evidence he would have understood 'empire' to refer to a composite state: for example, the terms 'English' or 'British

\footnotetext{
42 Locke, Essay, ed. Nidditch, 646 (IV. xii. 11). On Locke's anti-essentialism, see the discussions in Jeremy Waldron, God, Locke, and Equality: Christian Foundations in Locke's Political Thought (Cambridge, 2002), ch. 3, 'Species and the Shape of Equality', and Peter R. Anstey and Stephen A. Harris, 'Locke and Botany', Studies in History and Philosophy of Biological and Biomedical Sciences, 37 (2006), 151-71.

43 Locke, Essay, ed. Nidditch, 92 (I. iv. 12). In 'Draft B' of the Essay, Locke had made the same point using the example of another Virginia Indian leader, Tottepottemay: Locke, 'Draft B', § 12, in Drafts for the Essay, eds. Nidditch and Rogers, I, 120, drawing on [John Lederer,] The Discoveries of John Lederer, trans. Sir William Talbot (London, 1672), 7; Farr, 'Locke, "Some Americans", and the Discourse on "Carolina", 40-50.

44 Locke, 'Of Study' (27 March 1677), in Locke, Political Essays, ed. Goldie, 367.

45 Armitage, The Ideological Origins of the British Empire, 29-32.
} 
empire' appear nowhere in his writings. Nor did Locke anywhere conceive of an empire in terms that later theorists might have recognized: as a territorially defined, hierarchically organized polity which suspends diversity within unity, usually for the benefit of a metropolitan or other central authority. ${ }^{46} \mathrm{He}$ was, in regard to his strictly political theory (particularly in the Two Treatises of Government), a theorist of the commonwealth, or state, and not a theorist of empire. How, then, might he have come be identified as an imperial theorist?

Three answers might be given to that question, two historical and one more immediately textual. The first goes back to the eighteenth and early nineteenth centuries when Locke's opponents identified him as a theorist indebted to the experience of empire. Critics at that time focused on two particular features of his political theory: the prominence of Native Americans in his account of the state of nature, and the centrality of slavery to the colonial system imagined in the Fundamental Constitutions of Carolina. In this vein, shortly after Locke's death, his former pupil, the $3^{\text {rd }}$ Earl of Shaftesbury, condemned 'the credulous Mr. Locke with his Indian barbarian stories of wild nations' ${ }^{47}$ Sixty years later, the Anglican apologist, George Horne, later bishop of Norwich, similarly objected to Locke's appeal to the Native American example: 'This is not a state of nature, but the most unnatural state in the world, for creatures made in the image of God. And does a polite philosopher, in these enlightened days, send us to study politics under Cherokee tutors!'48 And during the American Revolution, the conservative Anglican dean of Gloucester, Josiah Tucker, argued repeatedly that the colonists' rebelliousness sprang from their attachment to Locke's political theory. Among his strategies for discrediting American revolutionary ideology was thus to attack the contractarian theories of 'Mr. LOCKE and his followers' on the grounds that they misleadingly deployed 'the Tribes of Savage Indians' as examples of human sociability in a state of nature: 'Let them not din our Ears with the examples of the Savages of

\footnotetext{
46 Compare Charles S. Maier, Among Empires: American Ascendancy and its Predecessors (Cambridge, MA, 2006), 20-1, on empire as 'a system of rule that transforms society at home even as it stabilizes inequality transnationally by replicating it geographically, in the core and on the periphery'. $473^{\text {rd }}$ Earl of Shaftesbury to Michael Ainsworth, 3 June 1709, in The Life, Unpublished Letters, and Philosophical Regimen of Anthony, Earl of Shaftesbury, ed. Benjamin Rand (London, 1900), 403-4.

48 George Horne, 'Mr. Locke, Consideration on His Scheme of an Original Compact' (in an Oxford assizesermon originally preached in 1769 and revised c. 1792), in The Reception of Locke's Politics, ed. Mark Goldie, 6 vols. (London, 1999), III, 229-38.
} 
America, as being any Proofs and Illustrations of their Hypothesis; - which, when thoroughly discussed, and accurately examined, prove just the contrary'. Locke and his disciples, Tucker continued, were either ignorant of the true nature of the Native Americans, 'or they must have acted a very disingenuous Part' in appealing to them. ${ }^{49}$ Shaftesbury, Horne, and Tucker shared the prejudices regarding the capacities of indigenous peoples associated with the high imperial vision. The critical distance between them and Locke is further evidence of how only with difficulty can he be assimilated to later imperial theories.

Locke's critics also accused him of hypocrisy with regard to another subaltern people entangled in the experience of empire: enslaved Africans and African Americans. Tucker, again, noted that in the Fundamental Constitutions, Locke 'lays it down as an invariable Maxim ... "That every Freeman of Carolina shall have ABSOLUTE POWER AND AUTHORITY over his Negro Slaves." How could this be reconciled with the statement in the opening lines of the Two Treatises of Government that 'Slavery is so vile and miserable an Estate of Man ... that 'tis hardly to conceived, that an Englishman, much less a Gentleman, should plead for't'? So much for 'the humane Mr. LOCKE! the great and glorious Assertor of the natural Rights and Liberties of Mankind'. Tucker thought that in this regard Locke was just like all 'Republicans', or what we would call liberals: that is, in favour of levelling all hierarchies above themselves while 'tyrannizing over those, whom Chance or Misfortune have placed below them' ${ }^{50}$ (This might be seen as an ancestor of the argument that liberalism as a 'creed' is exclusionary by its very nature.) Half a century later, in 1829, Jeremy Bentham used the same feature of the Fundamental Constitutions to ridicule Locke for his attachment to private property. If property-holding were the criterion for political participation, Bentham charged, then its reductio ad absurdum could be found among the slaveholders of the British Caribbean: 'Property the only object of care to Government. Persons possessing it alone entitled to

\footnotetext{
49 Josiah Tucker, A Treatise on Civil Government, in Three Parts (London, 1781), 200-1; J. G. A. Pocock, 'Josiah Tucker on Burke, Locke, and Price: A Study in the Varieties of Eighteenth-Century Conservatism', in Pocock, Virtue, Commerce, and History: Essays on Political Thought and History, Chiefly in the Eighteenth Century (Cambridge, 1987), 167-79.

50 [Josiah Tucker,] A Series of Answers to Certain Popular Objections, Against Separating the Rebellious Colonies, and Discarding them Entirely (Gloucester, 1776), 103-4; Tucker, A Treatise on Civil Government, 168; Locke, Two Treatises of Government, ed. Laslett, 141.
} 
be represented. West Indies the meridian for these principles of this liberty-champion': that is, Locke himself. ${ }^{51}$

The second historical answer to the question of how Locke could be thought of as a theorist of empire would be that his arguments were in fact often used in settler colonies around the world, and by other theorists who promoted European settlement beyond Europe, to justify the expropriation of indigenous peoples. For example, in the early eighteenth-century context of settler claims against the native title of the Mohegans of Connecticut, Locke could be excerpted to argue that the Indians were pre-civil peoples who had less right to the lands on which they lived than the more industrious English colonists. ${ }^{52}$ This so-called 'agriculturalist' argument gained its greatest purchase in the version inflected by Physiocratic political economy propagated by the Swiss jurist, Emer de Vattel, in his Droit des gens (1758), which argued that peoples who, 'to avoid labour, chuse to live only by hunting, and their flocks' pursued an 'idle mode of life, usurp more extensive territories than ... they would have occasion for, and have therefore no reason to complain, if other nations, more industrious, and too closely confined, come to take possession of a part of those lands'. From this argument, it followed that 'the establishment of many colonies on the continent of North America might, on their confining themselves within just bounds, be extremely lawful'. ${ }^{33}$ Vattel's arguments were widely dispersed across the globe by the circuits of empire in the late eighteenth and nineteenth centuries; their force could be felt when, for example, the Sydney Herald proclaimed in 1838 that Australia was for the Aborigines only 'a common - they bestowed no labour upon the land - their ownership, their right, was nothing more than that of the Emu or the Kangaroo'.54 This was a theoretical justification for the

51 Jeremy Bentham, 'Article on Utilitarianism' (8 June 1829), Bentham Papers, University College London, XIV. 432 (marginal note), 433.

52 John Bulkley, 'Preface', in Roger Wolcott, Poetical Meditations, Being the Improvement of Some Vacant Hours (New London, 1725), xv-lvi; Tully, 'Rediscovering America: The Two Treatises and Aboriginal Rights', in Tully, An Approach to Political Philosophy, 166-8; Craig Yirush, Settlers, Liberty, and Empire: The Roots of Early American Political Theory, 1675-1775 (Cambridge, 2011), ch. 4, 'John Bulkley and the Mohegans'.

53 Emer de Vattel, The Law of Nations (1758), eds. Béla Kapossy and Richard Whatmore (Indianapolis, 2008), 129-30 (I. vii. 81).

54 Quoted in Duncan Ivison, 'The Nature of Rights and the History of Empire', in David Armitage, ed., British Political Thought in History, Literature and Theory, 1500-1800 (Cambridge, 2006), 197; on the persistence of Vattelian arguments in nineteenth-century British imperial thought, see Gregory Claeys, 
foundations of property-holding in an imperial context; it was certainly Lockean in form but not directly Lockean in origin.

Like these imperial iterations of Locke's arguments, the third, textual, answer to the problem of Locke's identification as a theorist of empire goes back to the Two Treatises of Government. The allusions to non-European peoples in the Two Treatises are almost exclusively drawn from the Americas. There are only two passing references to Asia in the Treatises, one to the Chinese as 'a very great and civil People' (I. 141), the other to the deleterious consequences of absolute monarchy Robert Knox had portrayed in his 'late Relation of Ceylon' (1680) (II. 2) which Locke acquired in 1681.55 Otherwise, the historical and ethnographic examples Locke uses referred to 'Americans', meaning Native Americans, accompanied by occasional references to the creole settlers. Thus, in the First Treatise, Locke drew on examples from Peru, ${ }^{56}$ from the settlement of Carolina and the 'little Tribe[s]' 'in many parts of America', and from 'our late Histories of the Northern America' to ridicule Sir Robert Filmer's patriarchalism (I. 57, 145, 154). And in the same work, he twice alluded to the 'Planter', a 'Man in the West-Indies, who hath with him Sons of his own Friends, or Companions, Soldiers under Pay, or Slaves bought with Money', to disaggregate two forms of authority Filmer had conflated, political sovereignty and the power to make war, which Filmer had conflated (I. 130, 131).

The even more frequent allusions in the Second Treatise were likewise almost entirely confined to the native Americans. In that work, 'an Indian' stands beyond the reach of positive law made in Europe (II. 9). When 'a Swiss and an Indian' encounter each other 'in the Woods of America', they do so in a state of nature and hence are bound in their dealings by the laws of nature alone (II. 14). The Indians' family structures are flexible yet matrilineal: 'in those parts of America where when the Husband and Wife part, which happens frequently, the Children are all left to the Mother, follow her, and are

Imperial Sceptics: British Critics of Empire, 1850-1920 (Cambridge, 2010), 16-18, 108-9, 140, 202, 238, 263, 284-5.

55 Robert Knox, An Historical Relation of the Island of Ceylon (London, 1680), 43-7; Locke, Two Treatises of Government, ed. Laslett, 327 n. 12; Anna Winterbottom, 'Producing and Using the Historical Relation of Ceylon: Robert Knox, the East India Company and the Royal Society', British Journal for the History of Science, 42 (2009), 515-38.

56 Locke used the same example of Peruvian cannibalism from Garcilaso de la Vega in Locke, Essay, ed. Nidditch, 71 (I. iv. 9). On Locke and Garcilaso, see James W. Fuerst, 'Mestizo Rhetoric: The Political Thought of El Inca Garcilaso de la Vega' (PhD thesis, Harvard University, 2000), 349-405. 
wholly under her Care and Provision' (II. 65). A system of absolute monarchy in Europe would not ameliorate the instincts of a tyrant from across the Atlantic: 'He that would have been insolent and injurious in the Woods of America, would not probably be much better in a Throne' (II. 92). All political societies began not in natural hierarchy but consent, 'And, if Josephus Acosta's word may be taken, he tells us, that in many parts of America there was no Government at all' (II. 102). 'Conformable hereunto we find the People of America', Locke went on, 'who living out of the reach of the Conquering Swords and spreading domination of the two great Empires of Peru and Mexico, enjoy'd their own natural freedom' (II. 105). Such peoples had 'no Temptation to enlarge their Possessions of Land, or contest for wider extent of Ground' and 'the Kings of the Indians in America, which is still a Pattern of the first Ages in Asia and Europe' are 'little more than Generals of their Armies' (II. 108). They did not lack a medium of exchange but 'the Wampompeke of the Americans' was as incommensurable 'to an European Prince, [as] the Silver Money of Europe would have been formerly to an American' (II. 184). ${ }^{57}$

Fully half of Locke's allusions to the 'Americans' clustered in a single chapter of the Second Treatise, chapter V, 'Of Property'. His first image of the primal positive community God had bestowed on humanity before the invention of private property is the 'Fruit, or Venison, which nourishes the wild Indian, who knows no Inclosure, and is still a Tenant in common' (II. 26). This is the same Indian upon whom the 'Law of reason makes the Deer' his 'who hath killed it' (II. 30). Such goods show that '[t]he greatest part of things really useful to the Life of Man, and such as the necessity of subsisting made the first Commoners of the World look after, as it doth the Americans now, are generally things of short duration' (II. 46). Accordingly, the 'several Nations of the Americans are ... rich in Land, and poor in all the Comforts of Life' (II. 41), as can be shown by comparing '[a]n Acre of Land that bears [in England] Twenty Bushels of Wheat, and another in America ... of the same natural, intrinsick Value' but widely different productivity (II. 43). Anyone who 'plant[ed] in some in-land, vacant places of America' would not be able greatly to enlarge their possessions; even if they did, 'What would a Man value Ten Thousand, or an Hundred Thousand Acres of excellent Land, ready

57 On the comparability of currencies, including 'Wampompeak', in a colonial context, see also Locke, Further Considerations Concerning Raising the Value of Money, $3^{\text {rd }}$ edn. (1696), in Locke on Money, ed. Kelly, II, 426; William Molyneux to Locke, 6 June 1696, in Correspondence, ed. de Beer, V, 653. 
cultivated, and well stocked too with Cattle, in the middle of the in-land Parts of America, where he had no hopes of Commerce with other Parts of the World, to draw Money to him for the Sale of the Product' (II. 36, 48)? From that very fact Locke drew his famous conclusion: 'Thus in the beginning all the World was America, and more so than that is now; for no such thing as Money was any where known' (II. 49).

The prominence of these allusions to America in the Two Treatises, and their accumulation in the chapter 'Of Property', were in part the product of Locke's continuing relationship with Carolina in the early 1680s. During the summer of 1682, Locke was staying at the Earl of Shaftesbury's London residence at just the moment when the Carolina Proprietors were campaigning to revive the colony's fortunes and revised the Fundamental Constitutions to make their provisions more attractive to a wider range of potential settlers. A printed copy of the January 1682 Fundamental Constitutions survives with Locke's corrections and annotations, and provides evidence that America - and, by extension, empire of a specifically settler-colonial kind -- was much on his mind that summer. ${ }^{58}$ The most detailed examination of the composition and the dating of the Two Treatises suggests that Locke had begun the Second Treatise late in 1680 or early in 1681, laid it aside for a while, and then took it up again in early 1682 before completing the manuscript later that year. It seems likely that 'Of Property' was among the last chapters to be written, and that it was written separately from the rest of the Second Treatise, a speculation that would fit with the internal evidence of allusions to America in that chapter as well as the external evidence of Locke's involvement with the fortunes of Carolina. ${ }^{59}$ It would also explain why there seems to be a discontinuity between 'Of Property' and its surrounding chapters, 'Of Slavery' and 'Of Paternal Power', each of which treats non-political power and authority.

In composing 'Of Property', Locke needed to produce a justification of appropriation which would do double duty, both in England and in America. Locke contended that 'God gave the World to Men in Common; but ... it cannot be supposed he meant it should always remain common and uncultivated. He gave it to the use of the Industrious and Rational, (and Labour was to be his Title to it;) not to the Fancy or

58 The Fundamental Constitutions of Carolina (London, 1682), New York Public Library, call-number *KC + 1682; Armitage, 'John Locke, Carolina, and the Two Treatises of Government', 614-15.

59 J. R. Milton, 'Dating Locke's Second Treatise', History of Political Thought, 16 (1995), 389, 372-4. 
Covetousness of the Quarrelsom and Contentious' (II. 34). Each person has an exclusive right to his own body and therefore also of the labour of that body: "Whatsoever then he removes out of the State that Nature hath provided, and left it in, he hath mixed his Labour with, and joyned to it something that is his own, and thereby makes it his Property' (II. 27). Only after land had been appropriated in this way could it be apportioned 'by compact and Agreement' in those parts of the world where a monetary economy had been introduced and land had become scarce, just as the 'several States and Kingdoms ... have, by positive agreement, settled a Property amongst themselves in distinct Parts and parcels of the Earth', leaving 'great Tracts of Grounds' waste and lying in common, 'the Inhabitants thereof not having joyned with the rest of Mankind, in the consent of the Use of their common Money' (II. 45). ${ }^{60}$

The peculiar form of Locke's labour theory in the chapter 'Of Property' marked a shift in his own thinking on the legitimate method of individual appropriation from the original community of goods presented by God to humankind. ${ }^{61}$ As late as 1677-8, Locke had offered a broadly Grotian account of the process by which the primal positive community in the world had given way to the regime of exclusive private property. Locke argued that that process was contractual and that it was designed to prevent a state of anarchic competition for resources:

Men therefor must either enjoy all things in common or by compact determine their rights[.] if all things be left in common want rapine and force will unavoidably follow in which state, as is evident happynesse cannot be had which cannot consist without plenty and security. To avoid this estate compact must determin peoples rights. ${ }^{62}$

Such a contractual account of the origins of property could only refer to the agreements made between parties equally capable of entering into compacts with each other. In the

60 More generally on these passages, see David Armitage, 'John Locke's International Thought', in Ian Hall and Lisa Hill, eds., British International Thinkers from Hobbes to Namier (Basingstoke, 2009), 33-48.

61 On changes in theories of property, and in particular their relation to colonialism, see Kiyoshi Shimokawa, 'Property in the Seventeenth Century: Conventionalism, Unilateralism and Colonialism', in Peter R. Anstey, ed., The Oxford Handbook of British Philosophy in the Seventeenth Century (Oxford, forthcoming).

62 John Locke, 'Morality' (c. 1677-8), Bod. MS Locke c. 28, fol. 140, ptd. in Locke, Political Essays, ed. Goldie, 268; Richard Tuck, Natural Rights Theories: Their Origin and Development (Cambridge, 1979), 168-9. 
seventeenth-century context of relations between Amerindians and Anglo-Americans, the incomers did not always recognize the indigenous peoples' equal capacity with Europeans to determine rights by compact. However, the Fundamental Constitutions of Carolina had implicitly recognised the collective federative capacity of the Indians of Carolina when it twice mentioned 'treaties ... with the neighbour Indians' $(\S \S 35,50)$, but it expressly banned settlers from holding or claiming any land by 'purchase or gift' from native peoples ( $§ 112) .{ }^{63}$ The Indians' sovereignty (imperium) in terms of the law of nations was thereby distinguished from their rights of property (dominium), which were acknowledged neither as an attribute of their imperium over their territory nor as individually transferable attributes.

Locke's argument in 'Of Property' ensured, at the very least, that it would not be inconsistent with the justifications for appropriation upon which the Carolina colony was founded. A limited range of such justifications was available by the late seventeenth century. For example, Amerindian unbelief alone could not provide a justification for dominion because, as the Fundamental Constitutions specified, 'Idollatry Ignorance or mistake gives us noe right to expell or use [the Natives of Carolina] ill'. Locke himself later upheld just that same argument in his Letter Concerning Toleration (1685): 'No man whatsoever ought ... to be deprived of his Terrestrial Enjoyments, upon account of his Religion. Not even Americans, subjected unto a Christian Prince, are to be punished either in Body or Goods, for not imbracing our Faith and Worship'. ${ }^{64}$ Arguments from conquest would also have been implausible, for reasons Locke himself made clear in chapter XVI of the Second Treatise, especially because the right of the conquest even in a just war 'extends only to the Lives of those who joyn'd in the War, not to their Estates' or to their descendants (II. 182); to believe otherwise would be to deny the two basic natural rights possessed by 'Every Man': to freedom in his own person and 'before any other Man, to inherit, with his Brethren, his Fathers goods' (II. 191). For all these reasons, there could no legitimate appeal to a right of conquest in the Americas as the foundation for English imperium or dominium.

\footnotetext{
63 NA, PRO 30/24/47/3, fol. $66^{\mathrm{r}}$, ptd. in Locke, Political Essays, ed. Goldie, 180. This provision remained unaltered in all subsequent revisions of the Fundamental Constitutions.

64 [John Locke,] A Letter Concerning Toleration, trans. William Popple (London, 1689), 34.
} 
The only remaining argument was the contention (derived originally from Roman law) that dominion fell to those best able to cultivate the land to its fullest capacity, ${ }^{65}$ not least to fulfil the biblical command to subdue the earth (Genesis 1: 28, 9: 1). Precisely that argument underlay the rights claimed by the Proprietors over the land of Carolina, according to the terms of their grants from the English Crown. Thus, the original 1629 grant had called Carolina a region 'hitherto untilled ... But in some parts of it inhabited by certain Barbarous men', and Charles II reaffirmed this description in his 1663 grant which had charged the Lords Proprietors 'to Transport and make an ample Colony of our Subjects ... unto a certain Country ... in the parts of AMERICA not yet cultivated or planted, and only inhabited by some barbarous People who have no knowledge of Almighty God'. ${ }^{66}$ This agriculturalist argument was the best justification that could be given for colonial dispossession after arguments from contract, conquest and from grace had been gradually abandoned, and it was precisely this argument that Locke adopted in the Second Treatise.

Locke amplified the relevance of America to his arguments when he made a final set of manuscript revisions to the Two Treatises some time after 1698. The most extensive changes and additions he made were to the chapter 'Of Property' and sprang from his experience as a Commissioner on the Board of Trade in the late 1690s. First, he expanded his assessment of the benefits provided by cultivation and enclosure of land: 'he who appropriates land to himself by his labour does not lessen but increase the common stock of Man kind', by a factor of ten to one, or more likely 'it is much nearer an hundred to one. For I aske whether in the wild woods and uncultivated wast of America left to Nature, without any improvement, tillage or husbandry, a thousand acres yeild the needy and wretched inhabitants as many conveniencys of life as ten acres of equally fertill land in Devonshire where they are well cultivated?'. A few paragraphs later, Locke made a second addition which turned this observation into a tenet of

65 Anthony Pagden, 'The Struggle for Legitimacy and the Image of Empire in the Atlantic to c. 1700', in Nicholas Canny, ed., The Oxford History of the British Empire, I: The Origins of Empire (Oxford, 1998), 42-7; Lauren Benton and Benjamin Straumann, 'Acquiring Empire by Law: From Roman Doctrine to Early Modern European Practice', Law and History Review, 28 (2010), 1-38.

66 Charter to Sir Robert Heath (30 October 1629) and Charter to the Lords Proprietors of Carolina (24 March 1663), in North Carolina Charters and Constitutions, 1578-1698, ed. M. E. E. Parker (Raleigh, NC, 1963), 64, 76 (my emphases). 
economic reason of state for William III and his ministers. He had originally concluded a brief discussion of the multifarious forms of labour that go into the production of any commodity with a reflection on the relative unimportance of land to value: 'So little, that even amongst us, Land that is left wholly to Nature, that hath no improvement of Pasturage, Tillage, or Planting, is called ... wast'. In his revision, he went on, 'This shews, how much numbers of Men are to be preferd to largenesse of dominions and that the increase of lands [sc. hands?] and the right imploying of them is the great art of government. And that Prince who shall be so wise and godlike as by established Laws of liberty to secure protection and incouragment to the honest industry of Mankind against the oppression of power and narrownesse of Party will quickly be too hard for his neighbours' ${ }^{67}$

Such encouragement of industry was for Locke a matter of equal importance at home in Britain and across the Atlantic in America. Labour, he wrote in an essay on the English poor-law for the Board of Trade in 1697, was 'the burden that lies on the industrious'. Genuine relief for the poor 'consists of finding work for them, and taking care that they do not live like drones upon the labour of others'. A strict regimen of labour would have the benefit of providing education for the children of the poor who would be put to work in school, to ensure that they would no longer be 'as utter strangers both to religion and morality as they are to industry', perhaps like those natives of Carolina who, nearly twenty years earlier, the Fundamental Constitutions had deemed 'utterly strangers to Christianity' but who were not on that account to be dispossessed or ill-treated. ${ }^{68}$

These links among the Fundamental Constitutions, the Two Treatises, and the 'Essay on the Poor Law' suggest two conclusions regarding Locke as a theorist of empire

67 John Locke, manuscript additions to [Locke,] Two Treatises of Government, $3^{\text {rd }}$ edn. (London, 1698), 193, 197 (II. 37, 42), Christ's College, Cambridge, call-number BB 3 7a; Locke, Two Treatises of Government, ed. Laslett, $297 \mathrm{n}$. For recent discussions of these passages (but which ignore the evidence of their dating and context), see Edward Andrew, 'A Note on Locke's "The Great Art of Government", Canadian Journal of Political Science/Revue canadienne de science politique, 42 (2009), 511-19, and Lee Ward, 'A Note on a Note on Locke's "Great Art of Government"', Canadian Journal of Political Science/Revue canadienne de science politique, 42 (2009), 521-3.

68 John Locke, 'An Essay on the Poor Law' (September-October 1697), in Locke, Political Essays, ed. Goldie, 184, 189, 192; NA CO 388/5, fols. 232 ${ }^{\mathrm{r}}-48^{\mathrm{v}}$ (26 October 1697); Bod. MS Locke c. 30, fols. $86^{\mathrm{r}}-87^{\mathrm{v}}$, 94 ${ }^{\mathrm{r}}-95^{\mathrm{v}}$, 111; A. L. Beier, “'Utter Strangers to Industry, Morality and Religion”: John Locke on the Poor', Eighteenth-Century Life, 12 (1988), 28-41. 
that reinforce the evidence from his other works treated in this chapter. The first is that his was not a universalistic vision of English, British, or European superiority over the rest of the world and its peoples. It did not assume formal equality only for those deemed to be 'civil' peoples. Indeed, as Locke argued in a little-discussed passage in the Letter Concerning Toleration, even a Christian people, uprooted from their domestic setting and placed in an unfamiliar and dependent position, would be even more vulnerable than the 'pagans' among whom they settled:

An inconsiderable and weak number of Christians, destitute of every thing, arrive in a Pagan Country: These Foreigners beseech the Inhabitants, by the bowels of Humanity, that they would succour them with the necessaries of life: Those necessaries are given them; Habitations are granted; and they all joyn together, and grow up into one Body of People. The Christian Religion by this means takes root in that Countrey, and spreads it self; but does not suddenly grow the strongest. While things are in this condition, Peace, Friendship, Faith and equal Justice, are preserved amongst them.

Charity demands equal treatment for both pagans and Christians, and weakness leads to a fragile tolerance. However, the consequences of dominance and the assumption of religious rectitude bring not just intolerance but dispossession and destruction:

At length the Magistrate becomes a Christian, and by that means their Party becomes the most powerful. Then immediately all Compacts are to be broken, all Civil Rights to be violated, that Idolatry may be extirpated: And unless these innocent Pagans, strict Observers of the Rules of Equity and the Law of Nature, and no ways offending against the Laws of the Society, I say unless they will forsake their ancient Religion, and embrace a new and strange one, they are to be turned out of the Lands and Possessions of their Forefathers, and perhaps deprived of Life it self.

The conclusion Locke drew was Atlantic in form yet more general in application: 'For the reason of the thing is equal, both in America and Europe. And neither Pagans there, nor any Dissenting Christians here, can with any right be deprived of their worldly Goods 
... nor are any civil Rights to be either changed or violated upon account of Religion in one place more than another'. ${ }^{69}$

A second conclusion follows from the first: Locke's theory was non-hierarchical and inclusive to the extent that all adult humans possessed the same rationality because reason is likewise equal 'both in America and Europe' (and China, for example). As Locke put it in the Second Treatise, God gave the earth 'to the use of the Industrious and Rational', with labour as their means to earn title to it; yet the opposite of 'the Industrious and the Rational' in this passage were not the 'idle' and the 'irrational' but rather 'the Quarrelsom and Contentious': that is, anyone who exceeded 'the bounds, set by reason of what might serve for his use' and unjustly 'desired the benefit of another's Pains, which he had no right to' (II. 31, 34). The rational do have a right to possession, but only if they exercise their industry and do not invade the fruits of another's labour. Locke did not justify dispossession on grounds of any incapacity, whether mental or otherwise: if accumulation were pursued within the bounds set by reason, 'there could be then little room for Quarrels or Contentions about Property so establish'd' (II. 31). ${ }^{70}$ Least of all did he associate rationality with Europeans and irrationality with indigenous peoples. If any later settler colonialists sought an argument for indigenous dispossession on the grounds of their assumed innate rational superiority, as opposed to their lack of industry, only with some theoretical and historical difficulty could they have extracted such a justification from Locke's Second Treatise.

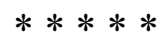

This chapter has tried to provide an account of Locke's conceptions of empire based on a full survey of his writings, in line with other recent discussions of his views, on slavery for example. ${ }^{71} \mathrm{I}$ hope to have shown that Locke's thought underwent change and that the historical Locke was necessarily more complex and often conflicted than

\footnotetext{
69 [Locke,] A Letter Concerning Toleration, trans. Popple, 35-6.

70 Compare Locke, Some Considerations, in Locke on Money, ed. Kelly, I, 292: 'Nature has bestowed Mines on several parts of the World: But the Riches are only for the Industrious and Frugal. Whomever else they visit, 'tis only with the Diligent and Sober only they stay'.

71 Especially Waldron, God, Locke, and Equality, 197-206; Farr, 'Locke, Natural Law, and New World Slavery'.
} 
later Lockeans - whether his followers or those who have analysed his work - have perhaps given him credit for being. The contextual and conceptual limits both to Locke's theories should remind us that diverse circumstances generated, and necessitated, differing strains of what has sometimes been aggregated as a single imperial 'liberalism' of which Locke is now held to be the progenitor. There is, for example, very little concrete evidence for the reception of Locke among Britons in the East Indies before the mid-nineteenth century: the Essay being read by an East India Company official in Sumatra in 1714; Locke's works in the baggage of Arthur Wellesley, the future duke of Wellington in 1796; and Philip Francis's knowledge of the economic writings may be about the sum of it. In 1769, Warren Hastings had expressed a hope for 'Lockes, Humes and Montesquieus in Number sufficient for each Department' to govern India through the East India Company. He would have been disappointed, at least in his desire for idiomatically Lockean administrators. ${ }^{72}$

Yet there can be no doubt that the shape of Locke's political theory owed decisive debts to his experiences as a colonial administrator and servant of the English state. Those experiences also placed limits on his universalism and ensured that later appropriations of his arguments would often have to reformulate them to fit later colonial contingencies. If indeed we are to use the anachronistic shorthand 'liberalism' to describe Locke's political theories, then we must be aware that there have been different strains of imperial and colonial liberalism and that they have not necessarily been continuous with each other. And if liberalism itself is to have the traces of its complicity with empire exposed and expunged, that will have to be undertaken in diverse and historically sensitive ways to create various post-colonial liberalisms, some of which may be able to draw robustly upon other Lockean legacies. ${ }^{73}$ For, as Locke himself put it with characteristically overbearing humility in 1692, 'you wonder at my News from the West-

\footnotetext{
72 Joseph Collet to Richard Steele, 24 August 1714, in The Private Letter Books of Joseph Collet, ed. H. H. Dodwell (London, 1933), 99-100 ('Mr. Lock who first taught me to distinguish between Words and things'); Philip Guedalla, The Duke (London, 1931), 55; Joseph Parkes and Herman Merivale, Memoirs of Sir Philip Francis, K.C.B., 2 vols. (London, 1867), I, 51-2; Ranajit Guha, A Rule of Property for Bengal: An Essay on the Idea of Permanent Settlement, 2nd edn. (Durham, NC, 1996), 97-8; Warren Hastings to George Vansittart, 23 December 1769, BL Add. MS 29125, fol. $22^{\mathrm{r}}$ (my thanks to Robert Travers for this reference). On the trajectory of 'liberalism' in India itself, see C. A. Bayly, Recovering Liberties: Indian Thought in the Age of Liberalism and Empire, 1800-1950 (Cambridge, 2011).

73 See Duncan Ivison, Postcolonial Liberalism (Cambridge, 2002), for one distinguished attempt.
} 
Indies, I suppose because you found it not in your Books of Europe or Asia. But whatever you may think, I assure you all the World is not Mile-End'. ${ }^{74}$

74 [John Locke,] A Third Letter for Toleration (London, 1692), 72. 